\title{
A survey of the impact of summer droughts in southern and eastern England, 1200-1700
}

\author{
Kathleen Pribyl ${ }^{1,2}$ \\ ${ }^{1}$ Climatic Research Unit, School of Environmental Sciences, University of East Anglia, Norwich, UK \\ ${ }^{2}$ Oeschger Centre for Climate Change Research, University of Bern, Bern, Switzerland \\ Correspondence: Kathleen Pribyl (k.pribyl@uea.ac.uk)
}

Received: 2 September 2019 - Discussion started: 24 September 2019

Revised: 21 February 2020 - Accepted: 3 March 2020 - Published: 12 June 2020

\begin{abstract}
Droughts pose a climatic hazard that had profound impacts on past societies. Using documentary sources, this paper studies the occurrence and impacts of spring-summer droughts in pre-industrial England from 1200 to 1700. The types of records, source availability and changes in record keeping over time are described, and an overview of droughts in those 500 years is provided. The focus lies on a structural survey over the drought impacts most relevant to human livelihood. This includes the agricultural and pastoral sectors of agrarian production, health, the fire risk to settlements, and the drop in water levels or dwindling of water supplies. Due to the specific characteristics of wheat cultivation in medieval and early modern England, the grain production was comparatively resilient to drought, whereas livestock farming was under threat when rainfall fell noticeably below average. Nonetheless, the most important problem in warm and dry summers was the risk to health. Partly steeply raised mortality levels were associated with these conditions during the study period because malaria, gastrointestinal disease and plague showed an affinity to heat and drought. Adaptation strategies to reduce the stress posed by summer droughts are included in the study.
\end{abstract}

\section{Introduction}

The occurrence of drought across the British Isles has attracted the attention of meteorologists since the nineteenth century. George James Symons' work on hydrometeorology is well known (1887). He was not only studying the rainfall patterns of his own time by establishing an extensive rain gauge network across the British Isles (Jones et al., 1997), but also investigated the occurrences of droughts over the past on the occasion of the 1887 drought (Symons, 1887). Brooks and Glasspoole (1928) based their work on past droughts on the catalogue of Symons. After them, most research has focused on the instrumental period, as by Jones et al. (1997), Briffa et al. (2009), Cole and Marsh (2006), Marsh et al. (2007), Todd et al. (2013), and Spraggs et al. (2015). Recently, Ireland's drought history was investigated by Wilby et al. (2016), Murphy et al. (2017) and Noone et al. (2017). Some of these works also include documentary data which are used for an evaluation of the drought conditions and impact research (Cole and Marsh, 2006; Murphy et al., 2017; Noone et al., 2017).

Drought in the pre-industrial period has received comparatively little attention. Using information in the form of direct weather references or proxy data in documentary sources, drought occurrence was included in the studies for England by Jones et al. (1984), Ogilvie and Farmer (1997), Pribyl (2017), and Pribyl and Cornes (2020a), and for Ireland by Dooge (1985). In recent decades, a new source for the study of droughts in the British Isles extending back to antiquity has become available, namely precipitation reconstructions based on tree-ring data (Cooper et al., 2012; Rinne et al., 2013; Wilson et al., 2013). These data have been integrated with data from continental Europe to produce gridded spatial fields in the Old World Drought Atlas (OWDA) by Cook et al. (2015) covering the last 2 millennia. However, uncertainty connected with tree-ring-based reconstructions of precipitation as indicated by Bothe et al. (2019) highlights the value of using documentary sources to verify the occurrence of historic droughts; this has been completed for several regions of Europe (Brázdil et al., 2018). 
Drought has rarely been the focus of studies by economic or agricultural historians, since across the British Isles severe harvest failures are mostly linked to excess rainfall. Hence, from Hoskins $(1964,1968)$ to Campbell $(2009,2016)$, research attention was concentrated on the impacts of wet extremes on agricultural output. In pre-industrial times such precipitation-induced harvest failures were the most common cause of subsistence crises. In their study of drought hazards in Ireland, Murphy et al. (2017) could even go so far as to state that the words "Irish drought" may be perceived as an oxymoron, even though drought does indeed pose a risk to modern-day Irish agriculture. In recent years, both historians and meteorologists have placed more emphasis on drought impacts in their research: Cole and Marsh (2006) included impacts in their survey of droughts in England and Wales after 1800; Stone (2014) investigated the subject in England for the 1320s and 1330s; Pribyl (2017) considered droughts and their impacts from the late thirteenth to the end of the fifteenth century; Pribyl and Cornes (2020b) gave a general overview over drought impacts in medieval and early modern England; and Murphy et al. (2017) focused on Irish nineteenth-century droughts.

Trenberth et al. (2014) found that under the conditions of global warming, some studies point to an increase in droughts over Europe, whereas other studies indicated a decrease. Hence, more research into past droughts is required. Briffa et al. (2009) found an increase in droughts in Europe, especially over central Europe; this increase was mainly due to higher temperatures in the years around 2000. In Ireland, fewer droughts were recorded over recent decades (Murphy et al., 2017), and even though droughts have affected England over this time, in popular memory they are still overshadowed by the drought of 1976; in general no increase in droughts in England could be noted before the middle of the first decade of the twenty-first century (Cole and Marsh, 2006).

This paper studies summer drought occurrence and impacts in the period 1200 to 1700 in pre-industrial England. It gives a short overview and examples of past droughts but does not constitute a catalogue. It rather attempts a structural survey of drought impacts on the most important fields of human life: the food supply - i.e. the agricultural and pastoral sectors - and health, which could be under threat by the outbreak of diseases or the decreased access to clean drinking water. The energy supply for flour or industrial mills, the availability of river transport, and the fire risk as well as adaptation strategies are also considered.

\section{The documentary sources}

The documentary sources used in this study come mainly from southern and eastern England (Fig. 1). Not only are these regions more vulnerable to drought than northern or western England (Cole and Marsh, 2006), but for most of

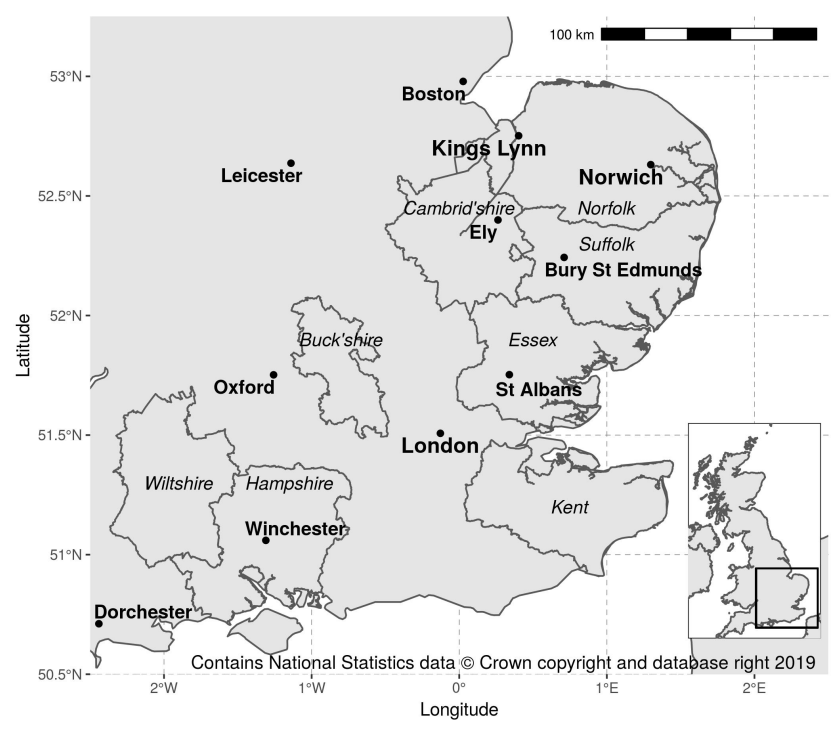

Figure 1. Map showing regions and cities in England described in the text. Counties indicate modern-day administrative boundaries.

the study period they dominate the historical record. Before 1200 , weather information exists going as far back as the Early Middle Ages, but it is at the beginning of the thirteenth century that the frequency and nature of the information permit a quantitative analysis (Ogilvie and Farmer, 1997). This paper focuses on droughts occurring in the summer half-year; droughts at this time of the year interfered with growing crops and herbage. Whereas severe droughts also caught the attention of townspeople, summer seasons with merely dry periods were more likely to be recorded in a rural setting by people involved in agriculture. The definition of seasons shifted over time in England. Medieval astronomers were already familiar with the division of the year based on the sun, but in general, in the Middle Ages - and in particular for people in the countryside - summer began when the growing season got under way, i.e. at a variable date in April or May. It lasted until the harvest season, autumn, which occurred in August and September. The end of the harvest season was marked by Michaelmas, 29 September, but winter was considered to start with the onset of wintry weather. Spring was perceived as an event rather than a season (Ogilvie and Farmer, 1997; Titow, 1960).

The documentary sources used in this paper are mainly of narrative nature, which means they primarily record extreme weather and its impacts; a sample of drought descriptions is provided in Table 1 (see Supplement). For the centuries up to 1600 the narrative sources are mostly chronicles, initially written by monks and later by lay persons from an urban background. For the sixteenth and seventeenth century, parish records and the Venetian State Papers provide information, and after c. 1620 the keeping of personal and farming diaries became popular. Administrative sources, such as manorial or municipal accounts, also provide direct and indi- 
rect information on past droughts; indirect information also reflects normal conditions. For the Middle Ages many manorial accounts survive; these supply data for agricultural and pastoral farming and often mention weather conditions interfering with these activities (Brandon, 1971; Pribyl, 2017; Stern, 2000; Titow, 1960, 1970). Using the narrative sources and the direct weather references from manorial accounts, Ogilvie and Farmer (1997) constructed monthly indices for temperature and precipitation for the period 1200 to 1430 .

Manorial accounts also often give information on the harvest length which is an indicator of the rainfall frequency and totals shortly before and during the harvest; for East Anglia this information has been collated into a precipitation index for the months July-September from 1256 to the mid-fifteenth century (Pribyl, 2017). After c. 1290 the data are almost continuous, and they help to identify extremes; they are particularly suitable for quantifying the interannual variation in precipitation. Averaged over 11 years the precipitation index follows the trends of tree-ring-based precipitation reconstructions from Norfolk and Hampshire - even though the temporal overlap of the precipitation index (JulySeptember) and the tree growing season (March/May-July) is limited (Fig. 2) (Brassley et al., 1988; Cooper et al., 2012; Jones and Baker, 1964; Pribyl, 2017; Wilson et al., 2013). The pivotal importance of rainfall conditions for the grain harvest is demonstrated by John Crakanthorp, who counted the rain days per harvest in his harvest diary 1682-89 (Brassley et al., 1988); essentially wet weather at harvest prolongs the drying time of the grain crop and wet grain is liable to spoil and to lose nutritional value.

\section{Characteristics of drought in England}

Jones et al. (1997) classified English droughts into short droughts of up to 9 months in length and ending in autumn or multi-annual droughts of 15-18 months duration containing in general two summers and one winter and having their greatest impact on the south-eastern part of Britain. Indeed dry years frequently cluster between 1800 and 2006 according to Marsh et al. (2007). The following section on droughts throughout the centuries demonstrates that this pattern also applies to medieval and early modern droughts. For the formation of multi-annual droughts, dry winters are also important and will therefore be briefly considered for the preindustrial period.

Marsh et al. (2007) and Todd et al. (2013) also identify long droughts, i.e. decades or even longer, when repeated periods of severe rainfall deficiency occur. In the documentary sources before 1700 the focus lies on intensive drought periods; hence it is mostly single-year droughts and short clusters that are described, whereas long droughts do not appear as such, probably also due to a certain level of acclimatization by the people. Nonetheless, on occasions the occurrence of long droughts can be deduced from the historical record. The
1240 s and early $1250 \mathrm{~s}$, the first decade of the $1300 \mathrm{~s}, 1325$ to c. 1340 , the second half of the 1380 s, the 1410 s, the 1470 s, the $1610 \mathrm{~s}$, the 1630s, and parts of the 1660s, 1670s and 1680s seem to fit this pattern.

\section{An overview of droughts $1200-1700$}

In the thirteenth century there is evidence in the documentary sources for prolonged dry conditions in spring and summer 1222, 1232 and in the mid-1230s (especially 1236, see Table 1). Drought also reigned during most of the $1240 \mathrm{~s}$, in the first half of the 1250s, in the early 1260s, in 1272 and the second half of the 1270s, from the mid-1280s to 1291, and in the last years of the century.

Probably the best-described drought of the thirteenth century came in 1252. Matthew Paris, a monk at St Albans, dedicated three paragraphs to this event (see Table 1). Between March and July it was dry and from April onwards also very warm. The lack of moisture impacted on the sown grain crops, and as the drought drew on, the landscape became parched, pasture was lacking, the cattle was wasting, the foliage was withered and the fruit and nut harvests lost, the soil cracked open, and even the birds suffered although there was a multitude of flies. Later in the summer a cattle murrain broke out and the people fell victim to disease. The problems encountered on the manors of the Bishopric of Winchester, which were situated in southern England centring on Hampshire, clearly fit this pattern: the ploughs broke on the hard soil, pea crops were lost, water levels dropped in the wells and pasture fell short; on one manor spring ploughing was impossible for 6 weeks (Titow, 1960). The drought and heat stretched across the Irish Sea to Ireland, where again water levels were low, trees burnt up in the sun and the grain harvest was very early (Hennessy, 1871). At harvest time rain arrived. The manorial accounts from the Bishopric of Winchester indicate that summer 1251 had already seen a dry period, and in 1253 another dry spring and early summer followed, a situation repeated in 1255 (Luard, 1880; Titow, 1960). Indeed this pattern was only broken with the year 1256 when the weather turned in mid-August and the very wet conditions, which were to dominate most of the second half of the 1250s, began.

During the fourteenth century England experienced drought conditions in the middle of the first decade, in the mid-1320s, the early and later 1330s, the early 1350 s, the early 1360s, the mid-1370s, the mid- and later 1380s, and the early 1390s. The drought in the mid-1320s and early 1330s is well documented (Anonymous, 1882; Aungier, 1844; Clyn, 1849; Titow, 1960) and its impact on farming has recently been studied in detail (Pribyl, 2017; Pribyl and Cornes, 2020a; Stone, 2014). In the post-Black Death environment fewer narrative sources are available for England, but in 1361 John of Reading and the Pipe Roll of the Bishopric of Winchester describe an exceptional drought affecting the country 


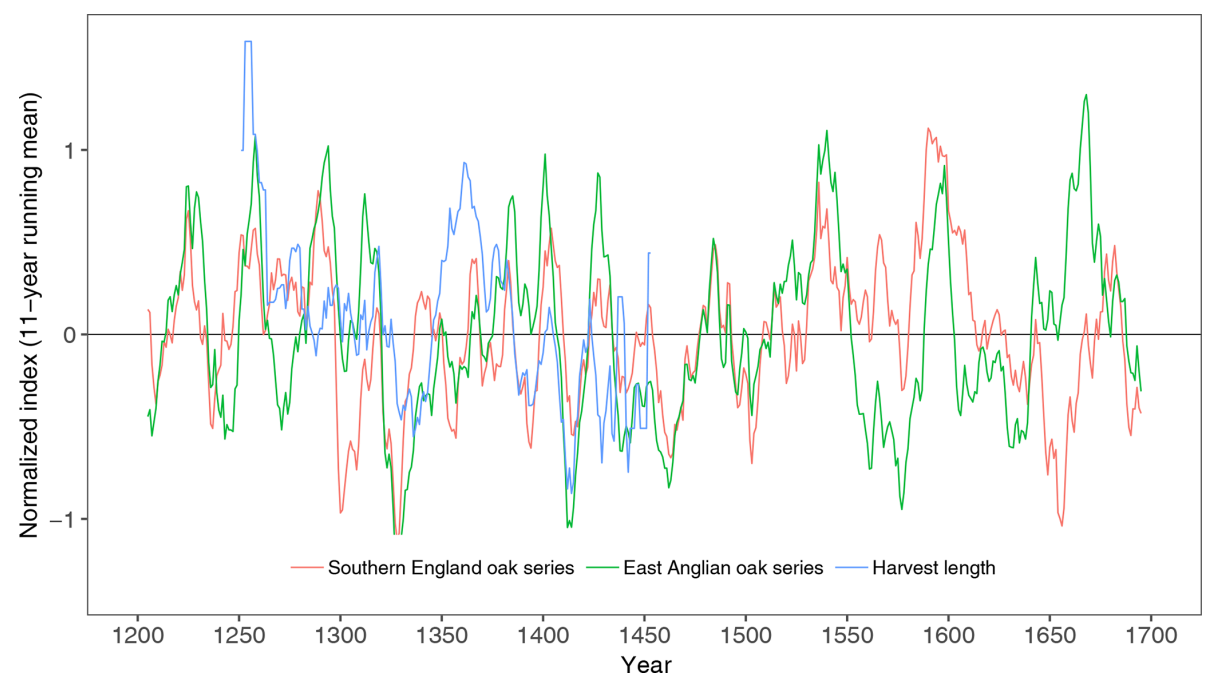

Figure 2. Time series of the tree-ring-based precipitation reconstructions by Wilson et al. (2013) for south-east England and by Cooper et al. (2012) for East Anglia, alongside the precipitation index for East Anglia by Pribyl (2017). Series are normalized over the period 1200 to 1700 .

(Titow, 1970; see Table 1). Grass and hay production suffered in particular; the drought was then followed by a "second spring" in October. The Winchester accounts also explicitly refer to heat, which is unusual for medieval sources. Indeed the spring-summer 1361 had the highest temperature in a reconstruction based on grain harvest dates for the period 1256-1431 (Pribyl et al., 2012; Pribyl, 2017). Grain prices rose in the aftermath of the harvest of 1361, and grain exports except to Ireland were forbidden, but the real calamity hitting the country in this year was the Second Pestilence, which killed c. $10 \%$ of the English population (Kerling, 1954; Pribyl, 2017).

The number of available written records dealing with weather dwindles further in the fifteenth century, probably reflecting the persistent negative demographic trend and the tensions of the War of the Roses. Nonetheless it is clear that the 1410s and the early 1430s were mostly dry. Drought and heat affected the country in 1464 and returned in the early and late 1470s. In 1473 the conditions were extreme and extended over wide parts of Europe (see Table 1). The drought of 1464 (see Table 1) coincided with a shortage of currency and the combined effect of these two factors led to low prices for foodstuffs; another plague wave took hold in the country. Again it was very hot and the spring grains, grass and hay suffered. In the marshland around Ely insects attacked cattle and people, and the death rate rose.

In the sixteenth century the number of available sources increases, particularly so for the second half of the century when climatic variations are recorded in greater detail. In the period to c. 1550 repeated warm and dry periods took hold, as in the later 1530s. After 1550 their frequency declined, but droughts still occurred as in $\mathbf{1 5 5 6}$ or in the early 1590s. In 1540 an exceptional drought affected large parts of
Europe, including southern England (see Pribyl and Cornes, 2020a). This summer half-year was so extreme that it constitutes a low-probability high-impact event (Glaser, 2013; Pfister, 2018; Wetter and Pfister, 2013).The London chronicles (see Table 1) all describe a sharp rise in mortality across the country due to agues, digestive disease and some plague occurrence. Cattle also died for lack of water, and water courses ran dry; even the Thames was so low as to allow salt water upriver from Old London Bridge. According to Charles Wriothesley it did not rain between June and late September (Old Style). The situation was so severe that Henry VIII as the head of the Church of England ordered the bishops to encourage prayer and processions; in London weekly processions began in mid-September (Old Style) (see Table 1). The continuator of Robert Fabyan mentions the drought and the ensuing diseases; he also describes the subsequent cold winter 1540-41 (see Table 1). ${ }^{1}$

Over the course of the seventeenth century the information on weather increases vastly even before the onset of instrumental measurements in the middle of the century: personal and farming diaries, newspapers, and notes in parish registers can all contain weather references. In this century droughts are noted in the 1610s, in the mid-1630s, in the early and late $1650 \mathrm{~s}$, during the second half of the $1660 \mathrm{~s}$ and $1670 \mathrm{~s}$, in the mid-1680s, and then around 1690. The drought in the mid-1630s is already well covered by written records. Winter 1633-34 had - at least in the south-west of the country - been wet, but the following spring was very dry, and until

\footnotetext{
${ }^{1}$ It should be noted, that most of the references to 1540 in English weather compilations such as Lowe's Natural phenomena and chronology of the seasons (1870), actually stem from Swiss sources and the English information has been erroneously dated to 1541 (Pribyl and Cornes, 2020a).
} 
midwinter there was such a rainfall deficit that springs and brooks failed and cattle needed to be driven over long distances to water (see Table 1). The drought affected the rest of southern England and East Anglia (Jones et al., 1984). The following winter was cold and long across the country (Blomefield, 1806; Whiteway, 1991). The summer season 1635 was dry again (Hinds, 1921), but the drought and heat then culminated in spring-summer 1636. Plague was present and the Venetian ambassador - used to a southern climate expected a great scarcity of victuals after a summer drought so severe that even the trees lost their leaves (see Table 1). In Essex then rain came on in August, damaging the harvest and causing a "michlemasse spring" of fresh growth in autumn (Webster and Shipps, 2004). Spring 1637, however, saw dry conditions again.

Dry winters are particularly important for the development of hydrological droughts because the groundwater storage is recharged between late autumn and early spring (Marsh et al., 2007). A convergence of cold, dry winters and warm, dry summers indicates an atmospheric blocking action over England; the historical records indicate that such a weather pattern was not infrequent in the past even though it has been rare over recent decades. Dry winters are rarely described in the written record, especially before the late sixteenth century. Records do mention dry and cold winters for 1224-25, 1233-34, 1325-26, 1516-17 and 1590-91; at least 1325-26 and 1590-91 were associated with drought conditions in the previous and following summers (Anonymous, 1865; Fabyan, 1811; Goring and Wake, 1975; Hamilton, 1875; Hewlett, 1889; Jones et al., 1984; Stow and Howes, 1631; Titow, 1960). The winter season 1613-14 also saw below-average rainfall and occurred in a decade of frequent dry summers. Winter 1664-65 was followed by a dry spring (Jones et al., 1984). For the last decades of the seventeenth century Anthony Wood, an antiquarian in Oxford, provides a record of dry cold winters: 1669-70 after the dry summer 1669 , 1675-76, lying between two drought summers, and 1678-79, which occurred between two spring seasons which saw dry periods (Clark, 1892). This pattern was maintained for $1684-85$, a severe winter on the whole, when hardly any precipitation fell throughout February and most of March as Wood and Robert Boyle noted (Clark, 1894; Cornes, 2020). The dry year 1684 had already been preceded by a dry cold winter in 1683-84 (Dobson, 1906; Gill and Guilford, 1910; Jones et al., 1984).

Dry winters are, however, normally cold winters, and cold winters are more frequently mentioned in the written records than dry winters, also before the late sixteenth century. Clustering of cold winters and dry summers during the study period was not untypical. Examples are the following cold winters, which were framed by two dry summers: 1247-48, 1253-54, 1304-05, 1305-06, 1332-33, 1338-39, 1339-40, 1413-14 and 1634-35 (Hewlett, 1889; Luard, 1876, 1880; Pribyl, 2017; Titow, 1960, 1970; Whiteway, 1991). Severe winters before dry summers are recorded for 1224-25, $1267-$
68, 1327-28, 1422-3 (Anonymous, 1865; Pribyl, 2017; Titow, 1960, 1970). The hard winter $1434-35$ was most likely preceded by an extremely dry summer as indicated by the OWDA (but the stream of documentary sources diminishes substantially during the decades of the mid-fifteenth century and hence no reference to the drought of 1434 survives) and summer 1435 was probably also dry (Anonymous, 1880b; Gregory, 1876; Harris, 1827; Langdon, 2004; Titow, $1970){ }^{2}$ Hard winters after summer droughts include 1225 26, 1268-69, 1288-89, 1291-92, 1309-10, 1329-30, 135859, 1407-08, 1416-17, 1464-65 and 1540-41 (Anonymous, 1866a, 1880a, b; Fabyan, 1811; Haydon, 1863; Herryson, 1840; Pribyl, 2017; Riley, 1864; Titow, 1960, 1970). In general during the dry decade of the $1410 \mathrm{~s}$, the cold and partly long winters 1409-10, 1412-13, 1413-14, 1416-17 and 1418-19 were preceded or followed by dry summer halfyears (Pribyl, 2017; Titow, 1970). Many of the hard winters between 1209 and c. 1450 are known from the Pipe Rolls of the Bishopric of Winchester and the vast majority of these winters were associated with dry summer seasons, a few with unexceptional summers and none with wet summers (Titow, 1960, 1970).

\section{Drought impacts}

\subsection{Agriculture}

Even when considering only this small sample of drought descriptions and the references in Table 1, the most important concerns of a pre-industrial society facing drought already become clear: agricultural and pastoral productivity, health, and falling water levels and their implications. In 1636 the Venetian ambassador expected scarcity to manifest itself in the foreseeable future, and grain crops of stunted growth or even non-germinating seed corn appear in sources for 1236, 1252 and 1361 (Luard, 1880; Tait, 1914; Titow, $1960,1970)$; in the latter year grain exports except to Ireland were stopped (Kerling, 1954). However, references to drought-related famines are conspicuously absent from the historical record. On occasion even a great abundance of grain is mentioned for harvests in dry summers as for 1287 and 1288 (Anonymous, 1866a; Ellis, 1859; Rishanger, 1865; Titow, 1960). In 1333 Ireland also enjoyed a plentiful harvest (Grace of Kilkenny, 1842; Titow, 1960) and in 1464 "[...] whete was worthe iiij d. a busshell, and all maner of vetaille grete chepe [...]" (see Table 1), although this was also connected to a currency shortage at that time, and the same occurred after the harvest of 1667 (Macfarlane, 1976).

The narrative and administrative sources reporting weather conditions, but also works on agriculture in England, confirm

\footnotetext{
${ }^{2}$ The mill at Birdbrook, Essex, stopped working due to a lack of water at some point between October 1435 and September 1436 (Langdon, 2004). The year 1436 is generally known to have been wet over Europe (Alexandre, 1987); thus autumn 1435 is more likely for the mill to have stopped working.
} 
that indeed "Drought never bred dearth in England" (Heywood, 1909). This idiom originates in the first half of the sixteenth century but probably reflects an even older attitude, and it remained common knowledge until at least the late nineteenth century (Inwards, 1994). Even though the optimum growing conditions vary from one cereal to another wheat, rye, barley and oats - as does their sensitivity to excess wetness or dryness, harvest success in the maritime climate of England is primarily threatened by excess rainfall, and subsistence crises are linked to wet growing and harvest seasons. None of the corn crops thrive in a wet summer, even though barley and oats bear such conditions better than wheat (Bowden, 1985). In particular, wheat in England during the study period was approaching the limits of its cultivation, and it would require more summer warmth and dryness than is generally provided in the region (Whitley, 1850; Simpson, 1850). Hence wheat suffered greatly in wet and cool summers, but essentially it was hardly ever too warm and dry for this crop in England (Bowden, 1985; Jones and Baker, 1964; Simpson, 1850; Whitley, 1850). In fact yield data from the extensive estates of the Bishopric of Winchester in southern England between 1209 and 1350 show that almost all outstandingly good harvests ( $15 \%$ above average) occurred under dry conditions: a very dry previous summer and autumn, followed often by a hard winter and then again by a very dry spring-summer (Titow, 1960). Until around the middle of the seventeenth century wheat was also mostly grown in the English vales, often on undrained clay soils, which increased the resilience of the grain crops to drought and exacerbated the impact of wet weather; the integration of higher ground into cereal cultivation helped to offset the effect of excess rainfall on the valleys (Jones and Baker, 1964). However, the comparative resilience of wheat to drought applies even to the conditions of modern agriculture in recent decades; in 1976 the wheat crop fell below average, but it did not fail (Carter, 1978; Martin, 2010). With progressing climate change and increasingly warm and dry conditions over England and Wales until 2050, wheat may actually be less vulnerable to summer drought than at present because the crop would mature earlier and hence avoid the peak of the dry summer weather (Semenov, 2009).

The notion that "Drought never bred dearth in England" can be traced beyond the sixteenth century. Around 1340 William Merle, a fellow at Merton College, Oxford, and rector of Digby in Lincolnshire, wrote his "Tractatus de pronosticacione aeris", ${ }^{3}$ an unusual work on weather forecasting, as it did not focus on using astrometeorological means, as was common at universities and courts in this era, but highlighted the observation of the "vulgar" signs of nature, such as the flight of birds, for short-term predictions. However, the "Tractatus" is also uncommonly practical in purpose, since it studies the influence of various weather types on agricultural production, particularly on the grain crops in an English con-

${ }^{3}$ Bodleian Library, Oxford, MS Digby 147, fols. 125-138. text. Merle is most likely the first to state that dry weather was good for wheat cultivation and that under drought conditions there could be no famine. This is not only borne out by contemporary yield and weather information by Titow (1960) for southern England, but also by the English wheat price (Munro, 2008). Considering the price in the context of growing season temperature and harvest season precipitation from 1264 to 1431 demonstrates that in general warm dry years were associated with low prices and the majority of harvests following on from these meteorological conditions lowered the price further. Warm and dry years also often lowered the wheat price after famines as in 1318 or later in 1651 and 1652. Sometimes drought was severe enough to be linked to a moderate increase in prices, but the occasions when the grain price rose substantially are rare; some of these rises can also be attributed to other (weather) factors and in no case was a subsistence crisis caused by a warm and dry summer alone (Jones et al., 1984; Munro, 2008; Pribyl, 2017).

Drought does, however, pose a risk for the spring crops barley and oats and for legumes, and Merle stated that these need humidity after sowing and are vulnerable to prolonged dry weather. In the late 1330s, when he was writing his treatise, he must have been aware of the impact of drought in the mid-1320s and early 1330s. This impact was geographically very varied - sometimes even from village to village - but significant (Stone, 2014). In particular, it is the effect that a lack of rainfall has on barley, a grain that also served as a bread corn in the Middle Ages, that chroniclers and reeves refer to when they mention that the corn did not germinate or was of stunted growth. Lost crops of legumes are also commonly described in the manorial accounts; peas and beans are drought sensitive (Pribyl, 2017; Pribyl and Cornes, 2020b; Stern, 2000; Titow, 1960, 1970). This form of scarcity is also observed by the Venetian ambassador in early summer 1636, which followed on the dry year 1635 , and based on his Italian background he anticipated a worsening of the scarcity due to the continuation of drought throughout summer 1636; however, he projected his Italian experiences on to England and this expected dearth did not manifest itself, grain prices remained stable after the harvest of 1636 , and only the price for peas had been rising substantially since 1635 (Munro, 2008). As Merle had pointed out, as long as one grain was sufficiently plentiful, and in drought this was wheat, there would be no famine. Merle's analysis was ahead of its time; the agricultural revolution in seventeenth-century England allowed this mechanism of replacing one grain with others to be employed also after harvest failures linked to wet and cold summers and hence helped to end famine in the country. With this substitution the demographic effects of the subsistence crisis were minimized (Appleby, 1979).

A possible exception to the rule that "Drought never bred dearth in England" must be considered: the year 1556. Not much is known about the weather in spring and summer 1556 , but the year played a role in massive rises in grain prices, the outbreak of disease and a consequent extreme 
rise in mortality. Some compilations such as Lowe (1870) or Short (1749) mark it as a year of drought, but it is not clear, if they based their judgement on English or continental sources. On the continent the conditions in 1556 were indeed extremely warm and dry; e.g. in the vine harvest date series of the Vienna hospital, 1556 was warmer than even 1540 (Buisman, 1998; Glaser, 2013; Kiss, 2018). Sources relating to the drought over the continent abound, but the spatial extension of the phenomenon to include England cannot be deduced from them. In a year when religious tensions ran high in England and the country's political and religious future was unsettled, few sources focus on the weather. Hence it is not surprising that some economic and social historians such as Hoskins (1964) assume that the very wet conditions occurred, as are classical in the development of dearth in England, while others stated a spring drought, though without giving the original evidence.

Jones et al. (1984) identify the summer season as dry based on Francis Blomefield's An essay towards a topographical history of the County of Norfolk (1806). Blomefield describes a dry summer during which, in several places, the turf caught fire and burnt for up to 2 weeks. Even though this publication is not a contemporary source for the mid-sixteenth century, Blomefield was using a manuscript of that time from the Norwich archives. Interestingly field and turf fires were also common across the North Sea in the Low Countries (Buisman, 1998). The last rainfall that can be traced for England in spring 1556 occurred on 21 March (Old Style) in Oxford at Cranmer's execution (Strype, 1694). Not much precipitation can have fallen after that because on 16 June (Old Style) the Venetian ambassador to England expected a "risk of great sickness and yet greater famine than the last, owing to the heat and extraordinary drought of the season, as, contrary to the wont of this climate, and to the need of the soil, 4 months and upwards have passed without any rain to do good" (Brown, 1877). The situation did not improve and by 7 July (Old Style) "intense heat" had joined the drought and "processions are made continually" to relieve the situation (Brown, 1877). By mid-August another complaint about the heat, which now affected Queen Mary, was added (Brown, 1877). The drought of 1556 probably even stretched far north up to Scotland, where the authorities in Edinburgh commissioned a new well and the deepening of three existing wells in July (Marwick, 1871). Even though the drought was underreferenced in the official sources of the time, it comes up in Protestant propaganda at the beginning of the reign of Elizabeth I, when a previous drought and dearth - undoubtedly in terms of the drought a description of 1556 and in terms of the dearth the years following the harvests 1555 and 1556 - were laid at the feet of the godlessness of Mary's reign, even though the author had spent those years in exile on the continent, where the drought haunted Catholic and Protestant lands alike (Scholefield, 1842). In Kent, it seems as if in the summer heat, the harvest was early and the spring corn, mostly barley, was too thin and of stunted growth in 1556 , so it could not be mown with short scythes. There were also possibly field fires in the county (see Table 1). In any case the harvest was poor and the grain prices rose to extreme heights afterwards (Munro, 2008). However, as the Venetian ambassador indicated, famine already reigned before the harvest of 1556 (Brown, 1877), and prices had indeed been on a trajectory to famine levels since the harvest of 1554 and reached them with the wet harvest of 1555 . Then in autumn 1555, at sowing time of the winter corn, heavy rainfall and flooding set in and must have damaged the seed or delayed sowing (Bowden, 1985; Grafton, 1809; Holinshed, 1808; Hamilton, 1877). Hence when scarcity was already bad, the droughtwithered spring corn could not be substituted with wheat or rye and full famine ensued. This pattern was also identified by Titow (1960) for the Middle Ages: a wet autumn followed by a dry spring could cause scarcity, although a run of wet conditions from autumn into spring or summer was more commonly linked to dearth and more severe harvest losses. In summer 1556 a multi-annual phase of high levels of disease and mortality began, which probably interrupted the harvesting, transporting and marketing of the grain further and could have contributed to raised grain prices.

\subsection{Pastoral farming}

In pastoral farming the impact of drought was more immediate that in agriculture: even a short drought, only lasting through spring and early summer, could wreak havoc. During the study period, livestock mainly depended on grass and hay and in some regions on green fodder crops like vetches, so spring and summer rainfall were essential. Turnips which have a different growing season, only appeared towards the very end of the study period (Overton, 1989). The growth of hay and herbage is limited or even ceases under drought stress. In early modern times, between 1640 and 1740, wheat and hay prices have been found to be generally inverted; that means years good for wheat (dry years) were bad for hay (Bowden, 1985). In the severe drought of 1976 the grass growth in spring was still adequate and potentially even higher in nutrition than normal, but then regrowth after mid-June to July was disappointing (Carter, 1978). The constraints on feed led to a collapse of milk production in dairy cattle herds in July and August, which took months to recover, even with the return of rain (Carter, 1978). Medieval manorial accounts mirror such conditions (Stern, 2000; Titow, 1960, 1970). Matthew Paris describes for 1252 how grass rubbed between the hands turned to dust (see Table 1). In the Middle Ages sheep's milk was also frequently used for cheese making in England, and sheep fare better in prolonged dry weather than cattle (Carter, 1978). In the drought of 1976 cattle remained lean at the end of summer, and both calves and lambs were underweight by September even with supplementary feed; for calves this was sometimes a drastic difference in weight compared to a normal year (Carter, 1978). Drought stress appears to have had an 
effect on the fertility of cows in the Middle Ages, which are often reported in manorial accounts to have been barren during and shortly after drought periods (Pribyl, 2017). The capacity of lean livestock to survive winter is obviously limited, but a lack of pasture and hay are even bigger factors in lowering winter survival rates (Bowden, 1985); hence livestock needs to be sold before winter (Jones and Baker, 1964). Acute desperation took hold when livestock was sold after winter (Jones and Baker, 1964), as observed by Josselin for cattle in early 1652 during the drought of 1651-53 (Macfarlane, 1976), indicating a delayed onset of grass growth. A short-term glut of livestock on the market for low prices would be followed by a longer period of high prices for the animals.

For the period 1200 to 1700 even more severe impacts are related to extreme droughts. Actual water shortage became a danger for cattle. In particular, cows with calves are in need of high amounts of water to maintain milk production (Carter, 1978), and Thomas Tusser (1812) states in the second half of the sixteenth century that cattle needed to be watered daily in summer. When water levels fell too much at pastures, cattle needed to be led to water; in the droughts of 1326, 1540 and 1634 this was sometimes over distances of 3-12 miles (Anonymous, 1882; Hamilton, 1875; Whiteway, 1991). For the summers of 1384 and 1540 it is reported that many cattle died due to a shortage of water (Hector and Harvey, 1982; Hamilton, 1877), although poisonous weeds, which might have been consumed by the animals when no grass was left (Carter, 1978), and heat stress might also have played a role in this raised cattle mortality. Heat stress, or potentially sun stroke, is attested to having killed people in England in 1473, when "in feld in harvist tyme men fylle downe sodanly" (see Table 1). In the worst case, the drought stress weakened the cattle so much that murrain could spread more easily, as in 1252 and 1662 (Dobson, 1997; Luard, 1880). Drought before 1700 thus had a high potential to disrupt pastoral farming, and the shortfall in livestock could cause a scarcity of dairy products and meat, which would negatively impact the diet of the poor in particular by reducing their access to protein and fat. Additionally, a cattle murrain could lower the number of draught animals, which in the medieval period were still often oxen not horses, and hence could have severe repercussions for transport and agriculture.

\subsection{Health: malaria, gastrointestinal disease and plague}

The most immediate and severe risk of drought to life in England between 1200 and 1700 did, however, not operate through the food supply but was a direct threat to health. In England, crisis mortality in pre-industrial times was primarily connected to either subsistence crises caused by extreme rainfall levels or to epidemics, but summer warmth exerted an influence over the death rate also in non-crisis years. For the period 1665 to 1834 - the post-plague period in early modern England - for which robust statistical data on mortality are available (beginning with the start of the parish registers in 1539), monthly death rates have been compared to food prices and monthly temperature averages from the Central England Temperature series by Lee (1981). The analysis reveals that food prices exerted a greater influence upon mortality than temperature, even though this was the age when famine was disappearing from England and the influence of prices on the death rate was waning over time. However, cold winters and warm summers also increased mortality and the impact of summer heat was stronger than that of the winter cold. Lee calculated that a warming of $1{ }^{\circ} \mathrm{C}$ in summer would raise the annual death rate by c. $4 \%$. Most of the additional deaths would fall in late summer and autumn, since the impact of summer heat on mortality was delayed by $1-2$ months.

Lee (1981) could not detect a significant influence of rainfall on mortality levels, but he only had access to annual rainfall totals, starting in 1727 , and not only are early rainfall data problematic, but annual rainfall totals are not necessarily representative of summer precipitation. Other data help to identify periods of drought and heat that were marked by high mortality throughout history: records of heriot payments, which were essentially a death duty, show a raised death rate amongst adults for areas mostly in eastern England from the mid-1320s to the early 1330s (Pribyl, 2017; Stone, 2014). Postan and Titow (1959) in their study of heriots on the Winchester manors between 1245 (advanced to 1209 by Titow, 1960) and 1350 found a number of years when mortality was high amongst villagers without an obvious connection to raised grain prices. Postan and Titow (1959) suspected drought-induced epidemic disease due to poor sanitation as well as a lack of or poor-quality drinking water as a cause for this increase in the death rate. Mortality was indeed raised in the months following the dry and hot summer $1288,{ }^{4}$ which is also described in the Annals of Dunstable (Anonymous, 1866a; Postan and Titow, 1959; Titow, 1960). Drought was also present during the mortality peaks in 1236, 1300 and 1328 (Luard, 1876; Pribyl, 2017; Titow, 1960). It seems to have played a role in the raised death rate of 1248 and in late 1272 , although these years were also times of dearth (Anonymous, 1885; Postan and Titow, 1959; Titow, 1960). ${ }^{5}$ Once the parish registers start, they immediately document the sharp rise in mortality during the drought summer of 1540, when hot agues, dysentery and plague were afflicting the English (Wrigley and Schofield, 1981, see Table 1). Awareness of the dangers of hot dry summers existed in early modern times (Appleby, 1980; Bacon, 1670; Dobson, 1997), and these hot and dry seasons did not increase the death rates by impact-

\footnotetext{
${ }^{4}$ Mistyped as 1287 in Titow (1960).

${ }^{5}$ For the other years of raised mortality, 1216, 1233, 1308, 1311 and 1342 , there is either no documentary evidence on weather available (1215-16) or the evidence does not show drought periods as a potential primary driver of the mortality (Titow, 1960; Symons, 1891; Stern, 2000).
} 
ing farming or food prices (Lee, 1981) but by directly contributing to the development of disease, as the case of 1540 demonstrates - often digestive disease and malaria.

Medieval and early modern narrative sources also frequently mention higher death rates and unidentified diseases in conjunction with heat and drought. These are partly reported as "fevers" or "agues" - terms which also include, but are not limited to, malaria - as in 1222, 1242, 1252, 1285, 1288 and 1305 (Anonymous, 1866a; Coggeshall, 1875; Hewlett, 1889; Luard, 1877, 1880; Rishanger, 1865; Postan and Titow, 1959). The period from the midfourteenth century to the mid-fifteenth century is dominated by a focus on plague epidemics, but after that non-plague disease is again reported for the summer droughts of 1464 , $1473,1540,1612,1616,1653,1657-58,1669-70$ and 1679 80 (Anonymous, 1880a; Dobson, 1997; Fabyan, 1811; Halliwell, 1839; Hamilton, 1875; Pribyl, 2017). Occasionally "quartan agues" or "fevers" are described in the records, i.e. fevers at $3 \mathrm{~d}$ intervals, which raises the chances of these references indeed being reports of malaria: in 1222 the source comes from eastern Essex, in 1242 from the well-informed Matthew Paris at St Albans, and in 1557-58 "quartan fevers" seem to have been part of the mixture of disease haunting the English during and after the famine (caused by the bad harvests of 1555 and 1556), although influenza was likely the main culprit of the enormous death rates (Appleby, 1980; Creighton, 1891; Fabyan, 1811; Hamilton, 1877; Holinshed, 1808; Stow and Howes, 1631). For 1252 Matthew Paris writes how the heat lasted throughout the nights, and flies, fleas and other insects made life miserable for men and beasts (see Table 1). This description possibly also refers to the activity of the nocturnal Anopheles mosquito, which acts as a transmission vector for malaria. In 1464, near Ely "great poisonous and horned flies" killed their victims quickly (see Table 1); whereas this seems to refer to horseflies, the amount of stagnant waters of that region - which were increased by the falling water levels during the drought - must have also been a breeding ground for other insects. Due to the geographical restrictions of the Anopheles mosquito, malaria was much more likely to occur in low-lying - and, in the study period, still largely undrained - wetlands. Examples of such wetlands are the marshlands around the Isle of Ely, those on the eastern and southern coasts, and those in the Thames estuary. Indeed many of the references to disease in drought summers mentioned above come from individuals that were in close geographical proximity to marshes, e. g. for 1222 by Ralph de Coggeshall (eastern Essex), or from well-informed observers who also showed a repeated interest in marshland, as for 1242 by Matthew Paris (Hertfordshire).

In the early modern period hot summers caused a sharp increase in mortality in south-eastern England; this summerautumn mortality occurred in uplands as well as wetlands, but it was much more pronounced in the latter (Dobson, 1997). Furthermore, in this regional setting the variability in summer-autumn mortality was more strongly connected to weather, in this case temperature, than mortality at other times of the year (Dobson, 1997). From 1661 to 1800 the correlation between July-August temperature and the burials in the following year was high in the marshlands; cool summers suppressed the death rate in the subsequent months (Dobson, 1997). Malaria was endemic in the marshes; by the nineteenth century infection resulted in illness rather than death for local adults, but children had more intense attacks and were at higher risk. In the early modern period the mean death rate, however, was 30\%-50\% higher in marshlands than elsewhere in south-eastern England (Dobson, 1997).

Gastrointestinal disease was another cause for increased mortality levels in and after drought summers; it particularly affected young children after weaning. The various forms of transmission, via contaminated water and food or via flies, were all enhanced during dry and warm summers, when water levels were low and, as described for 1252 and 1464, insect populations increased dramatically, especially in areas of standing water. Water could be made unsafe to drink by bacteria or algae; in 1409, for example, "blood is seen to gush forward from wells in diverse parts of England, and in consequence many died of dysentery" (Haydon, 1863, p. 415 , translation by the current author). The "bloody flux" or "laskes" [dysentery] were part of the diseases in 1473 and 1540. Gastric problems were also present in 1612, 1624, 1669-71, 1678-80, and possibly in 1616 and 1657-58 (Dobson, 1997). Again, the marshes were overly affected because in these regions and in the towns the access to clean drinking water was particularly difficult (Dobson, 1997) and flies found plenty of breeding grounds. The relationship between hot and dry conditions and increased (childhood) mortality due to digestive disease persisted well into the nineteenth century (Dobson, 1997).

As serious a threat as the various fevers like malaria and gastric infections may have posed, the disease that really raised alarm amongst the populace was plague. In the First Pestilence in the mid-fourteenth century more than a third of the English died; another $10 \%$ fell victim to the Second Pestilence 1361-62. Large-scale (in terms of geographical coverage and death toll) plague outbreaks marked the remaining fourteenth century; in the fifteenth century the outbreaks assumed a more regional and partly urban character and appear somewhat more scattered, although severe outbreaks returned in the second half of the century. Plague waves occurred every 5-12 years. In around 1500, Scotland and England began to implement measures intended to hinder the development and spread of the plague, such as quarantining, isolation, notification and travel bans. Up to about 1560 there seems to have been only a comparatively small number of severe outbreaks affecting the country, a picture that turned during the last decades of the century. Plague remained a serious threat until the last wave in 1665-66, and in England major plague waves caused higher death rates than famine in the sixteenth and seventeenth century (Appleby, 1980). Throughout the period plague was often present in 
London for long periods, although death rates due to plague during these phases remained generally low, apart from crisis years that sometimes overlapped with outbreaks in other parts of England.

When considering the relationship of the disease to meteorological factors, it is useful to focus on large-scale outbreaks. The Central England Temperature series starts in 1659 and hence hardly overlaps with the era of plague, and no yearly or seasonally resolved reliable temperature or precipitation index is available for England before 1659, so that the van Engelen (2001) temperature index from the Low Countries needs to be employed for the analysis; it can be supported by evidence from England. During the Middle Ages a specific weather pattern was associated with major plague outbreaks. Years of high plague mortality were generally marked by warm and dry summers; in any case these summers were warmer and drier than the previous summers, which were on the cooler or wetter side but never extremely cold or wet. The winter preceding the high plague mortality was not a hard winter; it could be of mild conditions or medium severity. Extremely cold winters were detrimental to plague: not only did they not precede severe plague years, they could also mark the end of a plague wave. Only a minority of plague outbreaks can be associated with cool and wet summer years, failed harvests and dearth, the most important examples being the First Pestilence in 1348-49, the Third Pestilence in 1369 and the plague wave just after the failed harvests in the second half of the 1430s (Pribyl, 2017). In fact, up to the end of the Middle Ages the relationship between warm and dry summers, which were at least noticeably warmer and drier than previous summers and did not follow on a cold winter or an extremely cold and wet summer, and major plague outbreaks was strong if 5-12 years since the last outbreak had passed. Such meteorological conditions without a plague wave only appear towards the end of the fifteenth century (Pribyl, 2017). In the subsequent centuries this relationship weakened, but the more substantial outbreaks of $1513,1532,1536,1563,1575,1578,1592-93$ and 159091 (south-west) and almost all those the seventeenth century (1603, 1609, 1635-36 and 1665-66) again coincided with the aforementioned weather pattern; early modern outbreaks can sometimes be traced back to the infection taking root in a port town. The plague outbreak of 1624-25 started under the standard conditions, but 1625 itself was cool and wet. However, in the sixteenth and seventeenth centuries other years offered the meteorological conditions for plague outbreaks and came after a 5-12 year interval since the last major outbreak but saw no major plague wave. It is outside the scope of this paper to speculate on the reasons behind this weakening of the relationship, i.e. whether this was due to human intervention, a change in the epidemiology of plague or increasing immunity. Again the high mortality due to plague in hot and dry years was not due to dearth - in London there was no link between plague mortality and bread prices in the sixteenth and seventeenth centuries (Appleby, 1975), nor were most major plague outbreaks in the Middle Ages linked to high food prices (Pribyl, 2017). The link between hot and dry summers and plague was known to contemporaries (Pribyl, 2017), and in his posthumously published work Sylva Sylvarum (1626/7) Francis Bacon stated, that "In England [...], many times, there have been great Plagues in dry years" (Bacon, 1670, p. 84).

\subsection{Fire risk}

A further risk in times of persistent dry weather was the increased chance of fires, particularly during multi-annual droughts. As London fell victim to the flames in the dry summer of 1666, so other town fires occurred during droughts, as in 1288 and 1303 in Boston and in 1326, when Royston, Wandsworth and the abbey of Croxden were consumed by fire (Anonymous, 1996; Aungier, 1844; Ellis, 1859, Rishanger, 1865). In 1389 and 1393 fires following on from thunderstorms destroyed villages in Kent; in spring 1394 fires were widespread in eastern England (Hector and Harvey, 1982; Anonymous, 1866b). When summers were extremely dry and hot, turf, fen or fields could also catch fire, as in 1556 in Norfolk (Blomefield, 1806) and possibly also in Kent (Beale, 1998). Norfolk also saw a sharp rise in field fires in the dry and warm summer of 2018.

\subsection{Water supply}

As mentioned above, low water levels threatened the health of people and livestock; they raised the risks of contamination of water sources or a lack of drinking water, particularly in marshland and in towns. The Thames remained a source of drinking water in London for a long time, and when the fresh water supply in the river dwindled, salt water would intrude towards the west of London Bridge further than normally. In 1326 Londoners had to content themselves with salty ale (Aungier, 1844). The Thames was also low in 1540 and 1592 (Stow and Howes, 1631). When the Thames dropped too low, then the barges between Oxford and London could not operate as in 1634, 1675-76 and 1685 (Clark, 1892, 1894; Jones et al., 1984). Water transport elsewhere was also hindered, as 1326 around the Isle of Ely (Anonymous, 1882). Springs drying up was common as is indicated in 1236, 1241, 1252, 1326, 1384, 1540 and 1619 (Anonymous, 1882; Aungier, 1844; Clyn, 1849; Grafton, 1809; Hamilton, 1875; Hall, 1809; Hector and Harvey, 1982; Holinshed, 1808; Jones et al., 1984; Luard 1877, 1880; Stow and Howes, 1631; Titow, 1960). The marshland itself also tended to be subject to falling water levels as is stated for 1236, 1241 and 1352 (Luard, 1876, 1877; Lumby, 1895). Falling river levels also reduced the availability of water power and affected industrial and flour mills. Explicit evidence for mills stopping working is given by Matthew Paris (Luard, 1876, 1877, 1880) for 1236, 1241 and 1253; the Pipe Rolls of the Bishopric of Winchester mention mills standing idle for a lack 
of water for 1248, 1268, 1327, 1336, 1337 and 1340 (Titow, 1960 ), and a mill also lacked water in 1435-36 (probably 1435) and 1619 (Jones et al., 1984; Langdon, 2004). When the mills could not grind the corn, a flour shortage would ensue, even if the harvest had been good and grain prices were not raised. In 1540 "people woulde haue giue one bushel [of grain] for the grindyng of another" (see Table 1), so the price for grinding was very high. Unsurprisingly disputes about water courses, their blockage or diversion, and mills often flared up in dry years.

\subsection{Flash flooding}

Paradoxically, droughts were also associated with flooding: once rainfall returned, the dried-up, hardened soil could often not absorb the water at sufficient speed and flash flooding was the consequence. This has been described for 1253 and 1393 (Anonymous, 1866b; Luard, 1880; Lumby, 1882; Riley, 1864).

\section{Adaptation measures: water supply, marshland drainage and fodder crops}

Since the severity of drought impacts was evident, it was not only individuals but also communities and institutions that adapted to the risk. Most pressing was the lack of water for people, industry and fire fighting, and hence improvements in water infrastructure, which might have been considered and planned for years before, are then actually carried out in a drought year. In 1240 the Countess of Devon brought water over 5 miles to her manor of Tiverton (Brooks and Glasspoole, 1928). In King's Lynn a cistern fed by pipes was installed in 1386 after at least two dry summers, and in 1474 the authorities in Norwich intended to construct two new wells after the extremely warm and dry summer of 1473 (Rawcliffe, 2013; Pribyl, 2017; Halliwell, 1839). The drought of 1556 seems to have stretched up to Scotland, where Edinburgh deepened three of its existing wells and undertook the construction of a new one (Marwick, 1871). The first water from springs outside Edinburgh arrived in the city in the drought summer of 1676 . After recognizing the need for a public water supply for more than a decade, Plymouth built Drake's Leat, which brought water from Dartmoor, in the multi-annual drought of 1590-91 (Brooks and Glasspoole, 1928) and Norwich replaced its well on the market with a pump in 1685 , the second dry summer half-year in a sequence (Blomefield, 1806). In London, the first water conduit is recorded for a drought year, 1236, and the New River, which was planned in 1602, was then begun in 1609 , a year marked by a dry spring and summer. In the severely dry year of 1612, which followed on the drought in summer 1611 , the king became directly involved in helping to counter difficulties of the project. The New River was completed in 1613. In the drought year of 1616, which again followed another severely dry summer half-year, the New River Com- pany was formed (Stow and Howes, 1631; Tomory, 2017). The number of customers of the New River water doubled during the drought summer of 1615 and increased by another third in the dry year of 1616 , but then growth slowed and stagnation and recession marked the 1620s; in the dry summers between 1630 and 1638 the number of customers doubled again (Tomory, 2017). Attempts were also made to offset the lack of water power by harnessing other sources of power, even though this is difficult to trace in the written record: in 1325-26, a multi-annual drought, a windmill was erected in East Knoyle, Wiltshire, and in 1408-09, when the latter year was dry, a horse mill was established in Ivinghoe, Buckinghamshire (Langdon, 2004; Pribyl, 2017).

There is evidence that droughts had the advantage of facilitating the drainage of the marshland; drained marshland would increase the available agricultural land. Already in the Middle Ages the draining of fenland occurred in times drier than average (Hallam, 1965). The obvious advantage of low water levels for drainage projects was also utilized when the seventeenth-century large-scale drainage was undertaken. In 1605 the Commissioner of Sewers for Norfolk noted that the long-lasting dry summer weather offered a good opportunity to act upon the royal wishes for draining the fenland (Morgan et al., 2010). The decision to drain the Great Fen in Cambridgeshire and Norfolk was taken in 1630, a dry summer half-year, and then carried out during the generally dry 1630s. A second phase occurred in the dry 1650s (Albright Knittl, 2007). As with the installation of an improved public water supply in growing towns, the wish to drain the marshland was long-standing, but then dry conditions either forced the authorities into action or offered an easy opportunity for a realization of plans.

The seventeenth century saw the beginning of the Agricultural Revolution. Not only was the sown acreage expanded and so grain output raised, but farming methods and productivity also improved. The cultivation of turnips in the second half of the seventeenth century was part of that change. Turnips served largely as animal feed and allowed higher levels of animal husbandry in areas, where pasture or hay were in short supply. However, considering the high frequency of drought summers in the 1660s, 1670s and 1680s - the period when turnips were introduced - the root vegetable also made it possible to offset the effects of drought on pasture and hay. Tubers are sown as late as August, when the negative effects of dry weather on grass and the hay crop were obvious, and turnips could hence supply extra winter feed in such years (Overton, 1989). Another way to ensure a supply of grass although not in defiance of a summer drought, but as a way to ensure an early fodder supply in spring - was the irrigation of meadow grass in the form of catchwork meadows or floated meadows; the latter system was elaborate and first described in 1610 but had come into operation in the years before 1600, whereas the first method is even older (Jones and Baker, 1964). 
As the drainage of the fenland raised the supply of arable land and pasture, contemporaries also considered the drainage efforts as a measure to improve public health. The vapours and smells of marshland were perceived as miasma, which was thought to be the cause of disease. However, the drainage of the marshes did indeed reduce the breeding grounds for the Anopheles mosquito and hence contributed to improved health, although the value of seventeenth-century drainage in this respect remains doubtful (Dobson, 1997). Elsewhere efforts for a better water supply and for sanitation and hygiene, such as improved street cleaning, must also have helped to reduce the effects of dry hot weather particularly on the occurrence of enteric fevers and maybe even plague.

\section{Conclusions}

Spring-summer droughts have been a feature of the climate in southern and eastern England over the centuries. Often the years marked by dry conditions clustered together. Severe droughts are known to have occurred in 1252, 1325$26,1361,1464,1540,1590-91,1636,1676$ and 1685. In medieval and early modern times, agricultural drought was rarely involved in the development of famines because the wheat crop was resilient to warm and dry conditions. The pastoral sector, however, came under immediate and potentially severe threat during spring-summer droughts. The hydrological aspects of drought impacted the water supply of people and livestock and also limited river transport and the energy supply of industrial and flour mills. Before the widespread use of stone in buildings, towns had a raised risk of fires spreading through the settlement in dry years. Drought - often going hand in hand with warmth in spring and summer - could severely affect health: outbreaks of malaria, gastrointestinal disease and plague often occurred in drought years.

Data availability. The tree ring data from Cook et al. (2015), Cooper et al. (2012) and Wilson et al. (2013) are available from the NOAA/NCEP paleoclimatology archive (https://www.ncdc.noaa. gov/data-access/paleoclimatology-data, NOAA, 2020).

The East Anglian July-September precipitation index from 1256 to 1448 is available in Appendix 5 of Pribyl (2017). All cited information from primary sources used in this article is referenced in the text.

Supplement. The supplement related to this article is available online at: https://doi.org/10.5194/cp-16-1027-2020-supplement.

Competing interests. The author declares that there is no conflict of interest.
Special issue statement. This article is part of the special issue "Droughts over centuries: what can documentary evidence tell us about drought variability, severity and human responses?'. It is not associated with a conference.

Review statement. This paper was edited by Stefan Grab and reviewed by Neil Macdonald and Alexander Hall.

\section{References}

Albright Knittl, M.: The design for the initial drainage of the Great Level of the Fens. An historical whodunit in three parts, Agr. Hist. Rev., 55, 23-50, 2007.

Alexandre, P.: Le climat en Europe au Moyen Âge, contribution à l'histoire des variations climatiques de 1000 à 1425, Paris, 1987.

Anonymous: Annales monasterii de Waverleia (AD 1-1291), in: Annales monastici, vol. 2, edited by: Luard, H. R., Longman, London, 129-411, 1865.

Anonymous: Annales monasterii de Dunstaplia (AD 1-1297), in: Annales monastici vol. 3, edited by: Luard, H. R., Longman, London, 3-419, 1866a.

Anonymous: Annales Ricardi Secundi et Henrici Quarti, Regum Angliae, in: Chronica monasterii S. Albani. Johannis de Trokelowe, et Henrici de Blaneforde ... chronica et annales, edited by: Riley, H. T., Rerum Britannicarum Medii Aevi Scriptores 28.3, Longman, London, 155-420, 1866b.

Anonymous: A brief Latin chronicle, in: Three fifteenth-century chronicles, edited by: Gairdner, J., new ser. 28, Westminster, 164-185, 1880a.

Anonymous: A short English chronicle, in: Three fifteenth-century chronicles, edited by: Gairdner, J., new ser. 28, Westminster, 180, $1880 \mathrm{~b}$.

Anonymous: Annales Paulini, in: Chronicles of the reigns of Edward I and Edward II., vol. 1, edited by: Stubbs, W., Rerum Britannicarum Medii Aevi Scriptores 76, Longman, London, 253370, 1882.

Anonymous: A continuation of the Historia Rerum Anglicarum, in: Chronicles of the reigns of Stephen, Henry II and Richard I., vol. 2, edited by: Howlett, R., Rerum Britannicarum Medii Aevi Scriptores 82, Longman, London, 503-583, 1885.

Anonymous: Hagnaby Chronicle, extracts, in: The medieval Lindsey Marsh, edited by: Owen, A. E. B., Boydell Press, Woodbridge, 63-73, 1996.

Appleby, A. B.: Nutrition and disease. The case of London, 1550-1750, J. Interdiscipl. Hist., 6, 1-22, https://doi.org/10.2307/202822, 1975.

Appleby, A. B.: Grain prices and subsistence crises in England and France, 1590-1740, J. Econ. Hist., 39, 865-887, 1979.

Appleby, A. B.: Epidemics and famine in the Little Ice Age, J. Interdiscipl. Hist., 10, 643-663, 1980.

Aungier, G. J. (Ed.): Croniques de London, depuis l'an 44 Hen. III jusqu'à l'an 17 Edw. III, John Bowyer Nichols and Son, London, 1844.

Bacon, F.: Sylva Sylvarum, or, a natural history in ten centuries, London and Westminster, 1670.

Beale, P. O.: A history of the post in England from the Romans to the Stuarts, Routledge, London and New York, 1998. 
Blomefield, F.: An essay towards a topographical history of the county of Norfolk, vol. 3: The history of the city and county of Norwich, part 1, E. Miller, London, 1806.

Bothe, O., Wagner, S., and Zorita, E.: Inconsistencies between observed, reconstructed, and simulated precipitation indices for England since the year $1650 \mathrm{CE}$, Clim. Past, 15, 307-334, https://doi.org/10.5194/cp-15-307-2019, 2019.

Bowden, P. J.: Agricultural prices, wages, farm profits, and rents, in: The agrarian history of England and Wales, edited by: Thirsk, J., Cambridge University Press, Cambridge, 1-118, 1985.

Brandon, P. F.: Late-medieval weather in Sussex and its agricultural significance, Transactions of the Institute of British Geographers, 54, 1-17, 1971.

Brassley, P., Lambert, A., and Saunders, P. (Eds.): Accounts of the Reverend John Crakanthorp of Fowlmere, 1682-1710, Cambridgeshire Records Society, Cambridge, 1988.

Brázdil, R., Kiss, A., Luterbacher, J., Nash, D. J., and Řezníčková, L.: Documentary data and the study of past droughts: a global state of the art, Clim. Past, 14, 1915-1960, https://doi.org/10.5194/cp-14-1915-2018, 2018.

Briffa, K. R., van der Schrier, G., and Jones, P. D.: Wet and dry summers in Europe since 1750. Evidence of increasing drought, Int. J. Climatol., 29, 1894-1905, 2009.

Brooks, C. E. P. and Glasspoole, J.: British floods and droughts, Benn, London, 199 pp., 1928.

Brown, R. (Ed.): Calendar of state papers and manuscripts relating to English affairs, vol. 6, 1555-1558, Her Majesty's Stationary Office, London, British History Online, available at: http://www. british-history.ac.uk/cal-state-papers/venice/vol6 (last access: 30 August 2019), 1877.

Buisman, J.: Duizend Jaar Weer, Wind en Water in de Lage Landen, vol. 3: 1450-1575, Franeker, 1998.

Campbell, B. M. S.: Four famines and a pestilence. Harvest, price, and wage variations in England, 13th to 19th centuries, in: Agrarhistoria på många sätt, 28 studier om människan och jorden. Festschrift to Janken Myrdal, edited by: Liljewall, B. and Myrdal, J., Skogs-och lantbrukshistoriska meddelanden, vol. 47, Gävle 2009.

Campbell, B. M. S.: The great transition. Climate, disease and society in the late-medieval world, Cambridge, 2016.

Carter, E. S.: The effect of drought on British agriculture, P. Roy. Soc. A, 363, 43-54, https://doi.org/10.1098/rspa.1978.0154, 1978.

Clark, A. (Ed.): The life and times of Anthony Wood, antiquary, of Oxford, 1632-1695, described by himself, vol. 2, Clarendon Press, Oxford, 1892.

Clark, A. (Ed.): The life and times of Anthony Wood, antiquary, of Oxford, 1632-1695, described by himself, vol. 3, Clarendon Press, Oxford, 1894

Clyn, J.: Annalium Hiberniae Chronicon ad annum MCCCXLIX, in: The Annals of Ireland together with the Short Annals of Irleand and the Annals of Ross, edited by: Butler, R., Irish Archaeological Society, Dublin, 1849.

Cole, G. A. and Marsh, T. J.: The impact of climate change on severe droughts. Major droughts in England and Wales from 1800 and evidence of impact, Environment Agency, 2006.

Cook, E. R., Seager, R., Kushnir, Y., Briffa, K. R., Büntgen, U., Frank, D., Krusic, P. J., Tegel, W., van der Schrier, G., AndreuHayles, L., Baillie, M., Baittinger, C., Bleicher, N., Bonde, N.,
Brown, D., Carrer, M., Cooper, R., Čufar, K., Dittmar, C., Esper, J., Griggs, C., Gunnarson, B., Günther, B., Gutierrez, E., Haneca, K., Helama, S., Herzig, F., Heussner, K.-U., Hofmann, J., Janda, P., Kontic, R., Köse, N., Kyncl, T., Levanič, T., Linderholm, H., Manning, S., Melvin, T. M., Miles, D., Neuwirth, B., Nicolussi, K., Nola, P., Panayotov, M., Popa, I., Rothe, A., Seftigen, K., Seim, A., Svarva, H., Svoboda, M., Thun, T., Timonen, M., Touchan, R., Trotsiuk, V., Trouet, V., Walder, F., Wazny, T., Wilson, R., and Zang, C.: Old World megadroughts and pluvials during the Common Era, Sci. Adv., 1, e1500561, https://doi.org/10.1126/sciadv.1500561, 2015.

Cooper, J. R., Melvin, T. M., Tyers, I., Wilson, R. J. S., and Briffa, K. R.: A tree-ring reconstruction of East Anglian (UK) hydroclimate variability over the last millennium, Clim. Dynam., 40, 1019-1039, https://doi.org/10.1007/s00382-012-1328-x, 2012.

Cornes, R. C.: Robert Boyle's weather journal for the year 1685, Weather, https://doi.org/10.1002/wea.3531, early view, 2020.

Creighton, C.: A history of epidemics in Britain. From AD 664 to the extinction of plague, Cambridge University Press, Cambridge, 1891.

de Coggeshall, R.: Chronicon Anglicanum, in: Radulphi de Coggeshall Chronicum Anglicanum, edited by: Stevenson, J., Rerum Britannicarum Medii Aevi Scriptores 66, Longman, London, 1$208,1875$.

Dobson, A. (Ed.): The diary of John Evelyn, MacMillan and Co., London, 1906.

Dobson, M. J.: Contours of death and disease in early modern England, Cambridge studies in population, economy, and society in past time: 29, Cambridge: Cambridge University Press, 1997, 1997.

Dooge, J. C. I.: Droughts in Irish history, in: Irish rivers, edited by: de Buitléar, É., Country House Press, Dublin, 26-28, 1985.

Ellis, H. (Ed.): Chronica Johannis de Oxenedes, Rerum Britannicarum Medii Aevi Scriptores 13, Longman, London, 1859.

Fabyan, R.: The new chronicles of England and France (The concordance of histories). Reprinted from Pynson's edition of 1516. The first part collated with the editions of 1533, 1542, and 1559; and the second with a manuscript of the author's own time, as well as the subsequent editions, London, xxi, 723, 1811.

Gill, H. and Guilford, E. L. (Eds.): The rector's book, Clayworth, Nottinghamshire, Henry B. Saxton, Notthingham, 1910

Glaser, R.: Klimageschichte Mitteleuropas. 1200 Jahre Wetter, Klima, Katastrophen, 3rd ed., WBG, Darmstadt 2013.

Goring, J. and Wake, J. (Eds.): Northamptonshire Lieutenancy papers, 1580-1614, Northumberland Press, Gateshead, 1975.

Grace of Kilkenny, J.: Annales Hiberniae, edited by: Butler, R., Dublin University Press, Dublin, 1842.

Grafton, R.: Grafton's Chronicle, or, History of England, to which is added his table of the bailiffs, sheriffs, and mayors of the city of London, from the year 1189 to 1558 , J. Johnson, F. C. and J. Rivington, T. Payne et al., London, 1809.

Gregory, W.: William Gregory's chronicle of London, in: The historical collections of a citizen of London in the fifteenth century, edited by: Gairdner, J., Camden Record Society (Old Series), [London], 1876.

Hall, E.: Hall's Chronicle, containing the History of England, J. Johnson, London, 1809. 
Hallam, H. E.: Settlement and society. A study of the early agrarian history of south Lincolnshire, Cambridge University Press, Cambridge, 1965.

Halliwell, J. O. (Ed.): Warkworth's chronicle of the first thirteen years of the reign of King Edward the Fourth, John Bowyer Nichols and Son, London, 1839.

Hamilton, W. D. (Ed.): A chronicle of England during the reigns of the Tudors by Charles Wriothesley, from A.D. 1485 to 1559, vol. 1., J. B. Nichols and Sons, London, 1875.

Hamilton, W. D. (Ed.): A chronicle of England during the reigns of the Tudors by Charles Wriothesley, from A.D. 1485 to 1559, vol. 2., J. B. Nichols and Sons, London, 1877.

Harris, N. (Ed.): A Chronicle of London, from 1089 to 1483, Longman, Rees, Orme, Brown and Green, London, 1827.

Haydon, F. S.: Continuatio Eulogii, in: Eulogium (historiarum sive temporis). Chronicon ab orbe condito usque ad annum Domini M.CCC.LXVI., a monacho quodam Malmesburiensi exaratum; accedunt continuationes duæ, quarum una ad annum M.CCCC.XIII., altera ad annum M.CCCC.XC. perducta est, Rerum Britannicarum medii aevi scriptores 9, Longman, Brown, Green, Longmans, and Roberts, London, 1863.

Hector, L. C. and Harvey, B. F. (Eds.): The Westminster Chronicle, 1381-1394, Oxford Medieval Texts, Clarendon, Oxford, 1932.

Hennessy, W. M.: The Annals of Loch Cé. A chronicle of social affairs, vol. 1., Longman, London, 1871.

Herryson, J.: Abbreviata cronica ab anno 1377 usque ad annum 1469, Publications of the Cambridge Antiquarian Society 2, Cambridge University Press, Cambridge, 1840.

Hewlett, H. G. (Ed.). Rogeri de Wendover liber qui dicitur Flores Historiarum, vol. 3, Rerum Britannicarum Medii Aevi Scriptores, Longman, London, 1889.

Heywood, J.: The play of the weather (1533), The Tudor Facsimile Texts, edited by: Farmer, J. S., T. C. \& E. C. Jack, London, 1909.

Hinds, A. B. (Ed.): Calendar of state papers and manuscripts relating to English affairs, vol. 23, 1632-1636, His Majesty's Stationary Office, London, British History Online, available at: http://www.british-history.ac.uk/cal-state-papers/venice/ vol23 (last access: 30 August 2019), 1921.

Hinds, A. B. (Ed.): Calendar of state papers and manuscripts relating to English affairs, vol. 24, 1636-1639, His Majesty's Stationary Office, London, British History Online, http://www. british-history.ac.uk/cal-state-papers/venice/vol24 (last access: 30 August 2019), 1923.

Holinshed, R.: Holinshed's chronicles of England, Scotland and Ireland, vol. 3, J. Johnson, F. C. and J. Rivington, T. Payne et al., London, 1808.

Hoskins, W. G.: Harvest fluctuations and English economic history, 1480-1619, Agr. Hist. Rev., 12, 28-46, 1964.

Hoskins, W. G.: Harvest fluctuations and English economic history, 1620-1759, Agr. Hist. Rev., 16, 15-31, 1968.

Inwards, R. (Ed.): Weather lore. A collection of proverbs, sayings and rules concerning the weather, Senate, London, 1994.

Jones, E. L. and Baker, T. H.: Seasons and prices. The role of the weather in English agricultural history, Allen \& Unwin, London, 195 pp., 1964.

Jones, P. D., Ogilvie, A. E. J., and Wigley, T. M. L.: Riverflow data for the United Kingdom. Reconstructed data back to 1844 and historical data back to 1556, CRURP, 8, Norwich, 1984.
Jones, P. D., Conway, D., and Briffa, K. R.: Precipitation variability and drought, in: Climates of the British Isles - present, past and future, edited by: Hulme, M. and Barrow, E., Routledge, London and New York, 197-219, 1997.

Kerling, N. J. M.: Commercial relations of Holland and Zeeland with England from the late 13th century to the close of the Middle Ages, E. J. Brill, Leiden, 1954.

Kiss, A.: Before and after the great heat and drought of 1540. Multiannual trends of grape and grain harvest dates in the Vienna hospital accounts, in: Genius loci. Laszlovszky 60, edited by: Mérai, D., Budapest, 117-120, 2018.

Langdon, J.: Mills in the medieval economy. England, 1300-1540, Oxford University Press, Oxford and New York, 2004.

Lee, R.: Short-term variation: Vital rates, prices and weather, in: The population history of England 1541-1871, edited by: Wrigley, E. A. and Schofield, R. S., Studies in social and demographic history, London, 1981.

Lowe, E. J.: Natural phenomena and chronology of the seasons, Bell and Daldy, London, 1870.

Luard, H. R. (Ed.): Matthæi Parisiensis monachi Sancti Albani, Chronica Majora, vol. 3, Rerum Britannicarum Medii Aevi Scriptores 57, Longman, London, 1876.

Luard, H. R. (Ed.): Matthæi Parisiensis monachi Sancti Albani, Chronica Majora, vol. 4, Rerum Britannicarum Medii Aevi Scriptores 57, Longman, London, 1877.

Luard, H. R. (Ed.): Matthæi Parisiensis monachi Sancti Albani, Chronica Majora, vol. 5, Rerum Britannicarum Medii Aevi Scriptores 57, Longman, London, 1880.

Lumby, J. R. (Ed.): Polychronicon Ranulphi Higden monachi Cestrensis, together with the English translations of John Trevisa and of an unknown writer of the fifteenth century, vol.8., Rerum Britannicarum Medii Aevi Scriptores 41, Longman, London, 1882.

Lumby, J. R. (Ed.): Chronicon Henrici Knighton vel Cnitthon, monachi Leycestrensis, Longman, London, 1895.

Macfarlane, A. (Ed.): The diary of Ralph Josselin, 1616-1683, Oxford University Press, London, 1976.

Marsh, T., Cole, G., and Wilby, R.: Major droughts in England and Wales, 1800-2006, Weather, 62, 87-93, https://doi.org/10.1002/wea.67, 2007.

Martin, J.: Long hot summers revisited, Rural Hist. Today, 19, 1-8, 2010.

Marwick, J. D.: Extracts from the records of the Burgh of Edinburgh, 1528-1557, Oliver and Boyd, Edinburgh and London, British History Online, available at: http://www.british-history. ac.uk/edinburgh-burgh-records/1528-57 (last access: 30 August 2019), 1871.

Merle, W.: Tractatus de pronosticacione aeris, MS Digby 147, fols. 125-138, Bodleian Library, Oxford, 1340.

Morgan, V., Rutledge, E., and Taylor, B. (Eds.): The papers of Nathaniel Bacon of Stiffkey, vol. 5, Norfolk Record Society 74, King's Lynn, 2010.

Munro, J.: Revisions of the Phelps Brown and Hoskins 'basket of consumables commodity' price series, 1264-1700, 2008.

Murphy, C., Noone, S., Duffy, C., Broderick, C., Matthews, T., and Wilby, R. L.: Irish droughts in newspaper archives. Rediscovering forgotten hazards?, Weather, 72, 151-155, https://doi.org/10.1002/wea.2904, 2017. 
NOAA: Tree ring data, available at: https://www.ncdc.noaa.gov/ data-access/paleoclimatology-data (last access: 1 July 2019), 2020.

Noone, S., Broderick, C., Duffy, C., Matthews, T., Wilby, R. L., and Murphy, C.: A 250-year drought catalogue for the island of Ireland, 1765-2015, Int. J. Climatol., 37, 239-254, 2017.

Ogilvie, A. E. J. and Farmer, G.: Documenting the medieval climate, in: Climates of the British Isles - present, past and future, edited by: Hulme, M., and Barrow, E., Routledge, London and New York, 112-133, 1997.

Overton, M.: Weather and agricultural change in England, 16601739, Agr. Hist., 63, 77-88, 1989.

Pfister, C.: The 'Black Swan' of 1540. Aspects of a European megadrought, in: Climatic change and cultural transition in Europe, edited by: Leggewie, K. and Mauelshagen, F., Brill, Leiden, 156-196, 2018.

Postan, M. M. and Titow, J.: Heriots and prices on Winchester manors, Econ. Hist. Rev., 11, 392-411, https://doi.org/10.2307/2591462, 1959.

Pribyl, K.: Farming, famine and plague: the impact of climate in late Medieval England, Springer, Cham, Switzerland, 2017.

Pribyl, K. and Cornes, R. C.: Droughts in medieval and early modern England, part 1: The evidence, Weather, 75, 168-172, https://doi.org/10.1002/wea.3599, 2020a.

Pribyl, K. and Cornes, R. C.: Droughts in medieval and early modern England, part 2: Impacts, Weather, https://doi.org/10.1002/wea.3529, early view, 2020b.

Pribyl, K., Cornes, R. C., and Pfister, C.: Reconstructing medieval April-July mean temperatures in East Anglia, 1256-1431, Clim. Change, 113, 393-412, https://doi.org/10.1007/s10584011-0327-y, 2012.

Rawcliffe, C.: Urban bodies. Communal health in late medieval English towns and cities, The Boydell Press, Woodbridge, xiii, 431 pp., 2013.

Riley, H. T. (Ed.): Chronica monasterii S. Albani. Thomae Walsingham Historia Anglicana, vol. 2, Rerum Britannicarum Medii Aevi Scriptores 28.1, Longman, London, 1864.

Rinne, K. T., Loader, N. J., Switsur, V. R., and Waterhouse, J. S.: 400-year May-August precipitation reconstruction for Southern England using oxygen isotopes in tree rings, Quaternary Sci. Rev., 60, 13-25, https://doi.org/10.1016/j.quascirev.2012.10.048, 2013.

Rishanger, W.: Chronica, in: Chronica monasterii S. Albani. Willelmi Rishanger, quondam monachi S. Albani, et quorundam anonymorum chronica et annals, vol. 2, edited by: Riley, H. T., Rerum Britannicarum Medii Aevi Scriptores 28, Longman, London, 1-230, 1865.

Scholefield, J. (Ed.): The works of James Pilkington, B.D., Lord Bishop of Durham, Cambridge University Press, Cambridge, 1842.

Semenov, M.: Impacts of climate change on wheat in England and Wales, J. R. Soc. Interface, 6, 343-350, https://doi.org/10.1098/rsif.2008.0285, 2009.

Short, T.: A general chronological history of the air, weather, seasons, and meteors, etc. in sundry places and different times; more particularly for the space of 250 years. Together with some of their most remarkable effects on animal (especially human) bodies and vegetables, printed for T. Longman and A. Miller, London, 1749.
Simpson, B.: Climate of the British Isles and its effects on cultivation, Journal of the Royal Agricultural Society of England, 1st ser., 11, 617-665, 1850.

Spraggs, G., Peaver, L., Jones, P., and Ede, P.: Re-construction of historic drought in the Anglian Region (UK) over the period 1798-2010 and the implications for water resources and drought management, J. Hydrol., 526, 231-252, https://doi.org/10.1016/j.jhydrol.2015.01.015, 2015.

Stern, D. V.: A Hertfordshire demesne of Westminster Abbey. Profits, productivity and weather, Studies in regional and local history, 1, edited by: Goose, N., University of Hertfordshire Press, Hatfield, 2000.

Stone, D.: The impact of drought in early fourteenthcentury England, Econ. Hist. Rev., 67, 435-462, https://doi.org/10.1111/1468-0289.12035, 2014.

Stow, J. and Howes, E.: Annales, or a general chronicle of England, Richard Meighen, London, 1631.

Strype, J.: Memorials of the most Reverend Father in God, Thomas Cranmer, sometime Archbishop of Canterbury, London, 1694.

Symons, G. J.: Historic droughts, British Rainfall, 23-35, 1887.

Symons, G. J. (Ed.): Merle's MS: consideraciones temperiei pro 7 annis, 1337-1344, London, 1891.

Tait, J. (Ed.): Chronica Johannis de Reading et Anonymi Cantuariensis, 1346-1367, Manchester University Press, Manchester, 1914.

Titow, J.: Evidence of weather in the account rolls of the Bishopric of Winchester 1209-1350, Econ. Hist. Rev., 12, 360-407, 1960.

Titow, J.: Le climat à travers les rôles de comptabilité de l'évêché de Winchester 1350-1450, Annales, Économies, Sociétés, Civilisations, 25, 312-350, 1970.

Todd, B., Macdonald, N., Chiverrell, R. C., Caminade, C., and Hooke, J. M.: Severity, duration and frequency of drought in SE England from 1697-2011, Clim. Change, 121, 673-687, https://doi.org/10.1007/s10584-013-0970-6, 2013.

Tomory, L.: The history of the London water industry, 1580-1820, Johns Hopkins University Press, Baltimore, 2017.

Trenberth, K. E., Dai, A., van der Schrier, G., Jones, P. D., Barichivich, J., Briffa, K. R., and Sheffield, J.: Global warming and changes in drought, Nat. Clim. Change, 4, 17-22, https://doi.org/10.1038/nclimate2067, 2014.

Tusser, T.: Five hundred points of good husbandry ... together with a book of huswifery; a new edition, with notes, georgical, illustrative, and explanatory, a glossary, and other improvements, edited by: Mavor, W. F., Lackington, Allen, and Co., London, 1812.

van Engelen, A. F. V., Buisman, J., and Ijnsen, F.: A millennium of weather, winds and water in the Low Countries, in: History and climate: memories of the future?, edited by: Jones, P. D., Ogilvie, A. E. J., Davies, T. D., and Briffa, K. R., Kluwer Academic/Plenum Publishers, New York et al., 101-124, 2001.

Webster, T. and Shipps, K. (Eds.): The diary of Samuel Rogers, 1634-1638, The Boydell Press, Trowbridge (Wiltshire), 2004.

Wetter, O. and Pfister, C.: An underestimated record breaking event - why summer 1540 was likely warmer than 2003, Clim. Past, 9, 41-56, https://doi.org/10.5194/cp-9-41-2013, 2013.

Wilson, R., Miles, D., Loader, N. J., Melvin, T., Cunningham, L., Cooper, R., and Briffa, K.: A millennial long March-July precipitation reconstruction for southern-central England, Clim. Dynam., 40/3, 997-1017, https://doi.org/10.1007/s00382-0121318-z, 2013. 